\title{
NEWS SECTION
}

\section{Composers}

Notes of premières of new works run from three months before to three months following publication of this issue, i.e. from 1 January to 30 June. There is therefore a three-month overlap between issues, and omissions and late news for the three 'following' months of the current issue will be picked up in the three 'prior' months of the next one. News of more distant forthcoming premières is given more briefly; full details will be found in subsequent issues.

JOHN ADAMS City Noir (UK première) - 11 March London, Barbican / London Symphony Orchestra c. composer. String Quartet (UK première) - 25 March London, St Luke's / St Lawrence String Quartet.

KALEVI AHO Minea (US première) - 11 March Philadelphia, Verizon Hall / Philadelphia Orchestra.

PEDRO AMARAL O Sonho (première) - 25 April London, The Place / Robert Howard Dance Theatre, London Sinfonietta c. composer.

LOUIS ANDRIESSEN Life (première) - 22 March Milan / Bang on a Can All-Stars.

DOMINICK ARGENTO The Choir Invisible (première) 16 May Washington DC / National Cathedral Choir c. J. Reilly Lewis.

RICHARD AYRES No. 42 (In the Alps) (UK première) - 17 March London, Queen Elizabeth Hall / Barbara Hannigan (sop), London Sinfonietta c. Martyn Brabbins.

FRANK MICHAEL BEYER Et resurrexit (première of complete work) - 12 March Leipzig, Peterskirche / MDR Rundfunkchor Leipzig c. Howard Arman.

HARRISON BIRTWISTLE Angel Fighter (première) - 13 June Leipzig, Thomaskirche / Daniel Taylor (counter-ten), Jeffrey Lloyd Roberts (ten), RIAS Kammerchor, musikFabrik c. Stefan Asbury.

DAVID BLAKE Scoring the Century (première) 4 March Birmingham, Conservatory Main Hall / opera dir. Keith Warner, c. Lionel Friend.

ELLIOTT CARTER Flute Concerto (UK première) 4 February Boston, Symphony Hall / Elizabeth Rowe (fl), Boston Symphony Orchestra c. James Levine. Nine by Five (première); Retracing II (première); Wind Rose (US première) - 11 February New York, Juilliard School / New York Woodwind
Quintet with William Purvis, Charles Neidich. Poems of Louis Zukofsky (UK première) - 24 March London, Wigmore Hall / Claire Booth (sop), Nash Ensemble. What Are Years (première) - 26 June Aldeburgh, Snape Maltings / Claire Booth (sop), Ensemble intercontemporain c. Pierre Boulez.

FRIEDRICH CERHA Trio for violin, cello and piano (première) - 14 January Antwerp / Altenberg Trio. Wie eine Tragikömodie (première) - 13 February Manchester, Bridgewater Hall / BBC Philharmonic c. HK Gruber.

SEBASTIAN CURRIER bodymusic (première) - 5 March New York, Miller Theatre / Manhattan Sinfonietta c. Jeffrey Milarsky.

MICHAEL DAUGHERTY Deus ex Machina (UK première) - 28 January Aberdeen / Terrence Wilson (pno), Royal Scottish National Orchestra c. David Danzmayr. Trail of Tears (première) - 25 March Omaha, NB / Amy Porter (fl), Omaha Symphony c. Thomas Wilkins.

BRETT DEAN Bliss (première) - 12 March Sydney, Opera House / dir. Neil Armfield, Opera Australia Chorus, Australian Opera and Ballet orchestra c. Elgar Howarth.

DAI FUJIKURA Double Bass Concerto (première) 3 June London, Queen Elizabeth Hall / Enno Senft (db), London Sinfonietta c. André de Ridder.

DETLEV GLANERT Wintersonnenwende (première) 25 April Hagen, Auditorium im Kunstquartier.

EDWARD GREGSON Dream Song (première) - 27 March Manchester, Bridgewater Hall / BBC Philharmonic c. Gianadrea Noseda.

HK GRUBER Busking (UK première) - 27 February Manchester, BridgewaterHall / Håkan Hardenberger (tpt), BBC Philharmonic c. composer. Into the open ... (première) - 11 June Vienna, Konzerthaus / Martin Grubinger (perc), Radio-Symphonieorchester Wien c. Peter Eötvös.

KIMMO HAKOLA Appassionato for cello and piano (première) - 22 February Turku / competitors in Turku Cello Competion. Symphony No. 1 (première) - 19 May Helsinki / Finnish Radio SO c. Sakari Oramo. 
HANS WERNER HENZE Opfergang (première) - 10 January Rome, Accademia Nazionale di Santa Cecilia / Ian Bostridge (ten), John Tomlinson (bar), Santa Cecelia Orchestra c. Antonio Pappano. Elogium (UK première) - 16 January London, Barbican / BBC Symphony Orchestra \& Chorus c. Oliver Knussen. Phaedra (UK première) - 17 January London, Barbican / Maria Riccarda Wesseling, John Mark Ainsley, Lauri Vasa, Alex Koehler, Ensemble Modern c. Michael Boder.

SIMON HOLT a table of noises (N. American première) - 10 February Toronto / Colin Currie (perc), Toronto SO c. Douglas Boyd.

ADRIANA HÖLSZKY Die Hunde des Orion (première) -24 April Witten, Tage für Neue Kammermusik.

NICOLAS A. HUBER Concerto for naturally-modulated soli and Ensemble (première) - 6 March Freiburg, SWR-Studio / Ensemble Aventure.

MÁRTON ILLÉS Scene polidimensionali XVII 'Die weisse Fürstin' (première) - 28 April Munich Biennale für neues Musiktheater, Gasteig / dir. Andrea Moses, c. Georg Fritzsch.

JOHANNES KALITZKE Die Besessenen (première) 19 February Vienna, Theater an der Wien / dir. Bech Holten, Klangforum Wien c. composer.

ELENA KATS-CHERNIN The Rage of Life (première) 24 April Antwerp, Troubleyn Laboratorium / Flanders Opera dir. Igor Bauersima, c. Daniel Inbal.

MAGNUS LINDBERGEXPO(UK première)-3 February London, Barbican / New York Philharmonic Orchestra c. Alan Gilbert.

JAMES MACMILLAN The Beneficiaries (première) - 25 February London, Purcell Room / Jane Manning (sop), Jane’s Minstrels. Etwas zurückhaltend (première) - 31 March Edinburgh, Canongate Kirk / Edinburgh Quartet. Violin Concerto (première) 12 May London, Barbican / Vadim Repin (vln), London Symphony Orchestra c. Valery Gergiev.

DAVID MATTHEWS Symphony No. 7 (première) - 24 April Manchester, Bridgewater Hall / BBC Philharmonic c. Gianandrea Noseda.

PETER MAXWELL DAVIES Sea Orpheus (première) 31 January Purchase, NY / Christopher Taylor (pno), Orpheus Chamber Orchestra.

THEA MUSGRAVE Sunrise (première) - 22 February New York, The Morgan Library / Les Amies with Carol Wincenc, Cynthia Phelps and Nancy Allen. Poets in Love (première) - 4 March Carlisle, PA, Dickinson College / The Florestan Project.
OLGA NEUWIRTH Remnants of Songs ... an Amphigory (German première) - 31 January Berlin, Haus des Rundfunks / Antoine Tanestit (vla), Deutsches Symphonie-Orchester Berlin c. Alejo Pérez.

HELMUT OEHRING mucity (première) - 9 February Münster / Sinfonieorchester Münster c. Fabrizio Ventura.

ARVO PÄRT Missa brevis for 12 cellos (première) 17 February Berlin, Konzerthaus / 12 Cellisten der Berlin Philharmoniker.

ANTHONY PAYNE The Period of Cosmography (première) - 6 June Manchester, Bridgewater Hall / BBC Philharmonic c. Gian Andrea Noseda.

WOLFGANG RIHM Das Gehege (UK première) 12 March London, Barbican / Gabriele Schnaut (singing actress), BBC Symphony Orchestra c. André de Ridder. Concerto 'Séraphin'(UK première) 13 March London, Barbican / London Sinfonietta c. Baldur Brönniman. Konzert in einem Satz for cello and orchestra (UK première) - 13 March London, LSO St Lukes / Steven Isserlis, BBC Symphony Orchestra c. André de Ridder.

NED ROREM Evidence of Things Not Seen; For Susan (UK premières) - 14 March London, Wigmore Hall / The Prince Consort.

CHRISTOPHER ROUSE Odna Zhizn (première) 10 February New York, Avery Fisher Hall / NYPO c. Alan Gilbert.

POUL RUDERS Handel Variations (première) - 14 January Aarhus, Musikhuset / Aarhus SO c. Giancarlo Andretta

KAIJA SAARIAHO The Tempest Songbook (première) - 16 January Orleans / Gaëlle Méchaly (sop), Stephen MacLeod (bass), Les Folies françoises. Emilie (première) - 1 March Lyon / dir. François Girard, Karita Mattila (sop), Orchestre de L'opera de Lyon c. Kazushi Ono.

AUliS SALLINEN Chamber Music VIII 'The Trees, All Their Green' (première) - 6 March Amsterdam, Muziekgebouw / Peter Wispelwey (vlc), Amsterdam Sinfonietta.

IRIS TER SCHIPHORST Die Gänsemagd (première) - 18 February Vienna / Wiener Taschenoper dir. Yevgeny Sitochin.

KURT SCHWERTSIK Nachtmusiken (première) - 16 January Manchester, Bridgewater Hall / BBC Philharmonic c. Gianandrea Noseda.

HOWARD SKEMPTON Two Guitar Interludes; Two Cello Interludes; Only the Sound Remains (premières) - 27 February Birmingham, CBSO Centre / Ulrich Heinen (vlc), James Woodrow (gtr), Christopher 
Yates (vla), Birmingham Contemporary Music Group c. James Weeks.

JOHN TAVENER Popule Meus (première) 6 February Winnipeg / Winnipeg SO c. Alexander Michelthwate.

MARK-ANTHONY TURNAGE Texan Tenebrae(première) - 21 January Santa Cruz de Tenerife / London Philharmonic Orchestra c. Vladimir Jurowski.

IAN WILSON Humpty Dumpty (première) - 18 March Lancaster, University / Dir. Elaine Tyler-Hall, Dov Goldberg(cl), Tim Williams (perc), Psappha Ensemble.

ZHOU LONG Madame White Snake (première) 26 February Boston, Cutler Majestic Theatre / Opera Boston c. Gil Rose.

\section{Books received}

(A listing in this column does not preclude a review in a future edition of Tempo)

The Cambridge Companion to Recorded Music edited by Nicholas Cook, Eric Clarke, Daniel LeechWilkinson and John Rink. Cambridge University Press, £50.00/\$90.00 (hardback), £18.99/\$29.99 (paperback).

Recorded Music. Performance, Culture and Technology edited by Amanda Bayley. Cambridge University Press, £55.00/ \$99.00.

August Halm. A Critical and Creative Life in Music by Lee A. Rothfarb. University of Rochester Press, $£ 50.00$.

Birtwistle - Mask of Orpheus by Jonathan Cross. Ashgate, £35.00.

Bernstein - West Side Story by Nigel Simeone. Ashgate, $£ 35.00$. 


\section{CONTRIBUTORS}

David Drew was born in London. His parents divorced before he was two; Drew was his mother's name. He was educated at Aysgarth prep school in Yorkshire, Harrow and Peterhouse, Cambridge. He began studying the life and music of Kurt Weill as early as 1952, and became pre-eminent among authorities on that composer. In the 1950s he collaborated with William Glock on The Score and on various performance projects, lectured at the Dartington Summer School, and edited The Decca Book of Ballet (published 1958). From 1959 till 1967 - with a brief spell as a BBC staff producer in 1960 he was the music critic of the New Statesman. He was editor of Tempo from 1971 into the early 1980s, and remained as Advisory Editor until 1992. From 1976 to 1992 he was Director of Publications for Boosey \& Hawkes Music Publishers. He was also European Representative of The Kurt Weill Foundation for Music, a member of the Editorial Board of the Kurt Weill Complete Edition, a Trustee of the BrittenPears Foundation, and from 1999 to 2001 Dramaturg for Broomhill Opera at Wilton's Theatre, London. As a record producer he was responsible for the Calouste Gulbenkian Foundation's project 'music today' (1961-76), releasing unfamiliar 20th-century music on the EMI and Argo labels, and later (199398) was artistic director for Largo Records, Cologne.

Ian Kemp was Lecturer in music at Aberdeen Univ. 1964-71 and Cambridge University 1972-6. Subsequently he was Professor of Music at Leeds University. 1977-81 and Manchester University. 1981-91. His books include studies of Tippett and Hindemith; he also edited Vol.13 of the New Berlioz Edition.

Alexander Goehr is Emeritus Professor of Music at Cambridge University. His recent works include Since Brass nor Stone for string quartet and percussion and an Overture for ensemble, and he has completed an 'opera in 24 preludes', Promised End, based on Shakespeare's King Lear.

Oliver Neighbour worked at the British Library for over 40 years and was superintendent of the Music Room of the Library from 1977 to 1987 . He is the author of many articles and The Consort and Keyboard Music of William Byrd (1977).

Karl Miller has been literary editor of The Spectator and the New Statesman, and editor (1967-73) of The Listener. In 1979 he founded the London Review of Books, which he edited until 1992. He was also Lord Northcliffe Professor of Modern English Literature and head of the English Department at University College, London. His books include Cockburn's Millennium (1975), Doubles (1985), a biography of
James Hogg (2004) and the memoirs Rebecca's Vest (1994) and Dark Horses (1998).

Hugh Wood's latest work is an arrangement of three early songs for mezzo-soprano and string orchestra, to be premièred at this year's Presteigne Festival.

David Matthews is a composer and writer. His Seventh Symphony will be premièred on 24 April at the Bridgewater Hall, Manchester, by the BBC Philharmonic conducted by Gianandrea Noseda. He is currently writing a Twelfth String Quartet for the Kreutzer Quartet.

Robin Maconie recently completed Notesfrom Oblivion: A Mozart in the Southern Ocean and Zeno's Arrow: Musical Knowledge from Plato to Cage.

Anthony Payne's orchestral work The Period of Cosmography will have its première by the $\mathrm{BBC}$ Philharmonic and Gian Andrea Noseda at the Bridgewater Hall, Manchester on 6 June as part of the Hallé/BBC Mahler Festival. With his wife Jane Manning he has contributed a joint chapter on Vocal Performance in the 20th Century onwards, in Cambridge University Press's forthcoming History of Musical Performance. Jane's comprehensive study of the vocal performance of Pierrot Lunaire - Voicing Pierrot-a Detailed Guide will be published by Southern Voices. This work was funded by a Creative Arts Research Fellowship at Kingston University awarded by the AHRC.

Elliott Carter's latest work is a song-cycle, What Are Years, to be premièred at this year's Aldeburgh Festival.

Annette Morreau, Founder/Director of the Contemporary Music Network, is the author of Emanuel Feuermann (Yale University Press, 2002) and a Fellow of the Bunting Institute, Harvard University. She is a leading London music critic, and Visiting Senior Research Fellow of Kings College, London University.

Tony Fell was Managing Director of Boosey \& Hawkes Music Publishers Ltd from 1974 to 1996.

HK Gruber has been appointed composer-conductor at the BBC Philharmonic in Manchester, in succession to James MacMillan; on 27 February he conducted the UK première of his trumpet concerto Busking there with Håkan Hardenberger as soloist. His symphony for percussion and orchestra, into the open ....will be premièred in Vienna on 11 June.

Janis Susskind is Director of Serious Music for Boosey \& Hawkes Music Publishers Ltd.

Rob Cowan has long been a frequent contributor to BBC Radio 3. He presented the first run of BBC Radio 3's weekly record magazine Off the Record, was 
a regular live guest on Record Review (precursor of the current CD Review), presented CD Masters (alongside Jonathan Swain, 2001-6) and The Cowan Collection (2003-6). Rob is a music critic/journalist for The Independent and is Contributing Editor and contributor for Gramophone. He spent 19 years with Boosey \& Hawkes, first in the education department, then as advertising manager and for the last eleven years, as the company's music archivist.

David Starobin is one of the leading classical guitarists in the USA, specializing in contemporary music; many composers have specially composed works for him. With his wife Becky he is founder and joint director of Bridge Records Inc.

Barrie Gavin is a television film-maker, who has specialised in documentaries on music over more than 45 years. He has had extended working partnerships with Pierre Boulez and Simon Rattle. Other films include 'Nali' on HK Gruber, 'Ikarus' on Igor Markevitch, and a series on contemporary music in the last days of the Soviet Union, made in collaboration with the writer Gerard McBurney.

Robin Holloway is a composer and writer on music who has taught at the University of Cambridge since the 1970s. He has recently arranged about 30 of Haydn's String Quartets for piano duet (available from http: / / www.fourhandsplus.com).

Kurt Schwertsik's orchestral work Nachtmusiken (whose third movement is entitled 'For David Drew ...') was premiered in Manchester on 16 January by the BBC Philharmonic Orchestra and on 23-24 February he was the focus of a two-day celebration hosted by the Royal Northern College of Music.

Howard Skempton's viola concerto Only the Sound Remains was premiered on 27 February in Birmingham by Christopher Yates (viola) and the Birmingham Contemporary Music Group conducted by James Weeks.

Gerard McBurney is currently living and working in Chicago.

Alison Latham has edited several books, including The Oxford Companion to Music (2001), and Sing, Ariel! (2003), a symposium for Alexander Goehr's Seventieth Birthday. For ten years she was Publications Editor at the Royal Opera House, Covent Garden.

Regina Busch lives in Vienna. She studied Mathematics in Cologne and Berlin and musicology in Berlin wiith Rudolf Stephan as well as performance theory and practice with Rudolf Kolisch. From 1980 to 1986 she collaborated in the Schoenberg Complete Edition in Berlin, and since 1986 has worked fulltime on the Alban Berg Complete Edition in Vienna. She is also collaborator in the project 'Correspondence of the Second Viennese School'. Her book on Leopold Spinner was published in Boosey \& Hawkes's 'Musik der Zeit' series in 1987.

Gillian Ward was David Drew's assistant from 1992 to 2009. She studied piano and cello (at Mozarteum, Salzburg), then vocal studies, and is administrator of Floral Opera, an informal educational group for opera singers. She was a Producer's Assistant at the BBC, principally for Leo Black, 1962-1977.

Stephen Walsh holds a personal chair in music at Cardiff University, which he joined as a senior lecturer in 1976. He is working on a study of Mussorgsky and the Russian nationalists. His major biography of Stravinsky was publishjed in two volumes in 2000 and 2006 .

Kim Kowalke has served, at Lotte Lenya's request, as President of the Kurt Weill Foundation for Music since 1981. He is also Professor of Musicology at the Eastman School of Music and the Richard L. Turner Professor in the Humanities at the University of Rochester. He has published widely on the music of Weimar Germany and on the American musical theater.

Martin Anderson, after 20 years in economics, writes on music for a variety of publications, including The Independent, International Record Review, International Piano and Pianist in the UK, Fanfare in the USA and Klassisk in Norway. He publishes books on music as Toccata Press; his CD label, Toccata Classics, was inaugurated in 2005.

Mark R. Taylor is currently Lecturer in Music at Oriel College, Oxford. His tribute to Horatiu Radulescu ('You Will Endure') receives its première this autumn, alongside his 8-movement piano cycle '...quaerere causas...'.

Bob Gilmore is a musicologist and keyboard player born in Northern Ireland. He studied at the University of York, England, at the University of California, San Diego (on a Fulbright scholarship), and at Queen's University Belfast. He is the author of Harry Partch: a biography (Yale University Press, 1998) and edited Ben Johnston: Maximum Clarity and other writings on music (University of Illinois Press, 2006), both of which recieved the ASCAP-Deems Taylor Award for works of excellence on American music. He is presently completing a biography of the French-Canadian composer Claude Vivier. He is founder member and keyboard player of Trio Scordatura, an Amsterdam-based ensemble performing microtonal music, and is a board member of the Stichting Huygens-Fokker, the Dutch society for microtonal music. He presently teaches at Brunel University in London. 
Helen Thomas, after a decade in music publishing followed by a career break for family, now lectures in music at Liverpool Hope University and administers The Cornerstone Festival. She is working on a PhD researching metaphor as a tool for the analysis of non-purposive music.

Paul Conway is a freelance writer and music critic, specializing in 20th-century and contemporary British music. He has reviewed for Tempo since 1997 and The Independent since 2000 and has provided sleevenotes for Lyrita, Dutton and Nimbus discs and programme notes for The Proms, Edinburgh and Spitalfields Festivals.

Geoffrey Alvarez is a composer and analyst who has recently conducted, in St John's Smith Square, the UK premières of works by Alexandre Tansman, Zygmunt Krauze (with the composer as pianist) and his own settings of poems by Robert Graves, My Last Muse, with the poet's last muse, Julia Simonne. He currently chairs an annual composition prize with his orchestra, the Alvarez Chamber Orchestra. American composer Molly Kien received the first prize for the 2009 competition Plucked from Nowhere for a work for harp and chamber ensemble. This, and a new concerto by Boguslaw Schaeffer written especially for the orchestra will be heard in the winter 2010/11 season. Opera director Keith Warner is involved in the preparation of Alvarez's full-length opera The King's Last Prophecy.

John Wheatley is an architect and, having been elected Freeman of the City of London, became Master of the Company of Chartered Architects from 1990 to 1991. He is an enthusiastic committee member of the London Sinfonietta, writes reviews on modern/new music for Tempo and, since his article 'The Sound of Architecture' appeared in October 2007 (Vol. 61 No. 243 ), has become engaged in a programme of illustrated lectures, uniting music with architecture and the Sussex Downs.

Peter Reynolds is a composer, writer and lecturer on music living in Cardiff. He is Artistic Director of PM Ensemble and the Lower Machen Festival and is a part-time member of the academic staff at the Royal Welsh College of Music and Drama.
Malcolm Miller is a musicologist and pianist, currently Associate Lecturer at the Open University, Tutor at the City Lit, and Director of the 'Forum for Israeli Music' of the Jewish Music Institute, SOAS, University of London. He is Editor of Arietta, Journal of the Beethoven Piano Society of Europe and a contributor to a wide variety of journals.

Jill Barlow is a freelance writer, music critic and pianist, based in the St Albans and London area. After eight years as weekly music critic for the St Albans Observer she has now moved on to specialize more in covering contemporary music and has reviewed for Tempo since 1999.

Arnold Whittall is Professor Emeritus of Musical theory and Analysis at King's College London.

Bernard Hughes is a composer. Forthcoming commissions include a new piece for the BBC Singers. The 'radio opera' The Death of Balder was shortlisted for the 2009 British Composer Awards. Bernard writes on contemporary music as 'The Earwig' for Sound and Music at www.soundandmusic.org/resources/ blog.

Bret Johnson is a practicing solicitor. His main musical activities are as an organist and choir director, and he regularly contributes articles for leading journals and newspapers on American music.

Brian Christopher Thompson is an instructor in the Department of Music at the Chinese University of Hong Kong. He is engaged in a number of biographical and cultural research projects centred on French-Canadian composers and has also written on Arthur Schnabel.

Peter Palmer has contributed to numerous music periodicals since 1971 as well as New Grove and MGG. He was founding editor of The Bruckner Journal. He has undertaken translation work for music publishers in the USA and Europe. His special interests include Symbolism circa 1900, 20th-century German and English songs and contemporary folk singers. 